Пробл. особо опасных инф. 2016; 1:33-39. DOI: 10.21055/0370-1069-2016-1-33-39

УДК 616.98:578.833.28

\author{
Е.В.Путинцева, В.П.Смелянский, Н.В.Бородай, В.В.Мананков, Г.А.Ткаченко, И.М.Шпак, \\ Д.В.Викторов, А.В.Топорков
}

\begin{abstract}
ЛИХОРАДКА ЗАПАДНОГО НИЛА В 2015 г. В МИРЕ И НА ТЕРРИТОРИИ РОССИЙСКОЙ ФЕДЕРАЦИИ. ПРОГНОЗ РАЗВИТИЯ ЭПИДЕМИЧЕСКОЙ СИТУАЦИИ В 2016 г.
\end{abstract}

\author{
ФКУЗ «Волгоградский научно-исследовательский противочумный институт», Волгоград, \\ Российская Федераџия
}

\begin{abstract}
Интенсивность эпидемических проявлений по ЛЗН в Российской Федерации в сезон 2015 г. была низкой, заболеваемость населения соответствовала межэпидемическому периоду. Всего зарегистрирован 41 случай болезни в 9 субъектах РФ. Заболеваемость ЛЗН населения в Европе и на Северо-Американском континенте несколько превышала показатели заболеваемости 2014 г., однако также не достигала эпидемических значений. Сезонное развитие эпидемического процесса ЛЗН на территории РФ демонстрирует тенденцию смещения пика заболеваемости населения на период начала осени в течении двух последних лет. Наличие маркеров ВЗН установлено в 2015 г. на 11 территориях РФ, а наличие иммунитета у населения к ВЗН - на 27. По данным молекулярно-генетического мониторинга, в 2015 г. на территории РФ продолжалась циркуляция ВЗН генотипов 1а и 2. Продолжающаяся тенденция изменения климатических условий в сторону потепления определяет высокую вероятность дальнейшего выявления циркуляции ВЗН в объектах внешней среды и появления случаев болезни на более северных территориях страны. Вероятность усиления интенсивности эпидемических проявлений ЛЗН в 2016 г. остается незначительной.
\end{abstract}

Ключевые слова: лихорадка Западного Нила, вирус Западного Нила, эпидемическая ситуация.

Корреспондирующий автор: Путинцева Елена Викторовна, e-mail: vari2@sprint-v.com.ru

E.V.Putintseva, V.P.Smelyansky, N.V.Boroday, V.V.Manankov, G.A.Tkachenko, I.M.Shpak, D.V.Viktorov, A.V.Toporkov

\title{
West Nile Fever across the World and in the Russian Federation in 2015. Forecast of the Epidemic Situation Development in 2016
}

\author{
Volgograd Research Anti-Plague Institute, Volgograd, Russian Federation
}

The intensity of epidemic West Nile fever (WNF) manifestations in the Russian Federation during the season, 2015 was low; morbidity rates coincided with those characteristic of inter-epidemic period. It total, 41 cases in $9 \mathrm{RF}$ constituent entities were registered. WNF incidence rates among the population in the territory of Europe and North-American continent slightly exceeded morbidity rates, 2014, but then again did not reach epidemic levels. During the past two years seasonal development of WNF epidemic process in Russia has had a tendency to defer the incidence climax to early autumn. The presence of West Nile virus (WNV) markers was established in 11 entities of the Russian Federation in 2015, and existence of immunity to WNV in the population - in the 27 territories. According to the results of molecular-genetic surveillance, in the territory of the Russian Federation in 2015 circulation of WNV genotype 1a and 2 continued. The ongoing changes of climatic conditions towards warming predetermine high probability of further WNV circulation in the environment and emergence of infection cases in areas of the country far to the north. However probability of WNF epidemic manifestations intensification in 2016 remains insignificant.

Keywords: West Nile fever, West Nile virus, epidemic situation.

Conflict of interest: The authors declare no conflict of interest.

Corresponding author: Elena V. Putintseva, e-mail: vari2@sprint-v.com.ru

Citation: Putintseva E.V., Smelyansky V.P., Boroday N.V., Manankov V.V., Tkachenko G.A., Shpak I.M., Viktorov D.V., Toporkov A.V. West Nile Fever across the World and in the Russian Federation in 2015. Forecast of the Epidemic Situation Development in 2016. Problemy Osobo Opasnykh Infektsii [Problems of Particularly Dangerous Infections]. 2016; 1:33-39. (In Russ.). DOI: 10.21055/0370-1069-2016-1-33-39

По данным Европейского центра по предотвращению и контролю за заболеваниями (European Centre for Disease Prevention and Control, ECDC, http://ecdc.europa.eu/), на 23.11.2015 г. в государствах, входящих в Европейский союз (ЕС), зарегистрировано 108 случаев лихорадки Западного Нила и 162 - в сопредельных странах (за исключением Российской Федерации). В 2014 г. на этих территориях зарегистрировано 195 случаев ЛЗН. Наибольшая заболеваемость в сезон 2015 г. зарегистрирована в Израиле - 123 случая (в 2014 г. - 31), Италии - 61 (в 2014 г. - 24), Сербии - 28 (в 2014 г. - 76), Румынии 19 (2014 г. - 23), Венгрии - 18 (2014 г. - 11) [7].
Заболеваемость населения ЛЗН в 2015 г. на Северо-Американском континенте была следующей. В США, по данным Центра по контролю и предотвращению заболеваний США (Centers for Disease Control and Prevention, $C D C$, http://www.cdc.gov/), на 17.11.2015 г. зарегистрировано 1812 случаев ЛЗН, из них $65 \%$ с нейроинвазивной формой инфекции (в 2014 г. - 1935 случаев, из них 59,4 \% - нейроинвазивная ЛЗН) [5]. В Канаде в сезон 2015 г., по данным Агентства общественного здравоохранения (Public Health Agency of Canada, PHAC, http://www. publichealth.gc.ca), выявлено 78 случаев ЛЗН (в сезон 2014 г. - 21) [6]. 
Число выявленных больных ЛЗН в субъектах РФ в 2015 г. (в сравнении с 2014 г.)

\begin{tabular}{|c|c|c|c|c|}
\hline \multirow{2}{*}{ Субъекты РФ } & \multicolumn{2}{|c|}{2015 г. } & \multicolumn{2}{|c|}{2014 г. } \\
\hline & Всего больных & В том числе летальных & Всего больных & В том числе летальных \\
\hline Центральный федеральный округ & 5 & - & 5 & - \\
\hline Белгородская область & 0 & - & 1 & - \\
\hline Воронежская область & 3 & - & 4 & - \\
\hline Липецкая область & 1 & - & - & - \\
\hline Калужская область & 1 & - & - & - \\
\hline Северо-Западный Федеральный округ & 1 & - & 0 & - \\
\hline Санкт-Петербург & 1 & - & - & - \\
\hline Южный федеральный округ & 21 & - & 11 & - \\
\hline Астраханская область & 15 & 1 & 5 & - \\
\hline Волгоградская область & 0 & - & 5 & - \\
\hline Краснодарский край & 1 & - & & - \\
\hline Ростовская область & 5 & - & 1 & - \\
\hline Приволжский федеральный округ & 14 & - & 10 & - \\
\hline Саратовская область & 10 & - & 1 & - \\
\hline Самарская область & 4 & - & 9 & - \\
\hline Уральский федеральный округ & 0 & - & 1 & - \\
\hline Челябинская область & 0 & - & 1 & - \\
\hline Итого: & 41 & 1 & 27 & 0 \\
\hline
\end{tabular}

По данным, предоставленным Управлениями Роспотребнадзора по субъектам Российской Федерации (РФ) в Референс-центр по мониторингу за возбудителем ЛЗН на базе Волгоградского научноисследовательского противочумного института, в 2015 г. на территории страны зарегистрирован 41 случай (в 2014 г. - 27) [3] лихорадки Западного Нила в 9 субъектах РФ (в 2014 г. - в 8) четырех федеральных округов, из них в Центральном - 5, СевероЗападном - 1, Южном - 21, Приволжском - 14. Сведения о числе зарегистрированных случаев ЛЗН в субъектах РФ приведены в таблице.

В феврале 2015 г. зарегистрирован 1 завозной случай ЛЗН - заражение жителя Санкт-Петербурга при посещении Таиланда.

По данным эпидемиологического расследования специалистов ФБУЗ «Центр гигиены и эпидемиологии» (далее ЦГиЭ) в субъектах РФ, отмечены случаи завоза ЛЗН внутри Российской Федерации: в Ростовскую область - с заражением на территории Дагестана, в Краснодарский край - с заражением в Ростовской области, в Калужскую область - с заражением в Краснодарском крае (в 2014 г.).

Эпидемическая ситуация по лихорадке Западного Нила в 2015 г. в России характеризовалась следующими проявлениями. В сезон 2015 г., как и в 2014 г., не наблюдалось выраженного эпидемического подъема заболеваемости. Интенсивность эпидемических проявлений ЛЗН была низкой, заболеваемость регистрировалась только в старых очагах (Астраханской, Ростовской, Воронежской, Саратовской, Самарской, Липецкой областях и Краснодарском крае).

Эпидемический сезон продолжался с мая по сентябрь, как и в 2014 и 2013 гг. [1, 2]. В течение сезона заболеваемость населения регистрировалась неравномерно, пик заболеваемости, как и в 2014 г., наблюдался в сентябре (53,6 \% от зарегистрированных случаев), всего на период август-сентябрь пришлось $78 \%$ от общего числа случаев заболевания. Наблюдения за сезонным развитием эпидемических проявлений ЛЗН на территории России отчетливо демонстрируют тенденцию смещения пиков заболеваемости населения на период конца лета - начала осени в течении двух последних лет, тогда как в предыдущие годы основное число случаев ЛЗН наблюдалось в июле-августе с абсолютным пиком в августе, например, в сезон 2013 г. в июле-августе зарегистрировано $82 \%$ от общего числа случаев ЛЗН, а максимум заболеваемости отмечен в августе (53\% от общего числа случаев).

Как и в предыдущие сезоны, в структуре заболеваемости преобладали клинические формы ЛЗН без поражения центральной нервной системы (в среднем по России -83 \%, в 2014 г. - 86 \%). Нейроинвазивные формы ЛЗН в 2015 г. составили в среднем по РФ $17 \%$ (в 2014 г. - 14 \%). Однако в отдельных субъектах значительно преобладали нейроинвазивные формы. Так, в Ростовской области из 5 выявленных больных у троих (60 \%) имелись поражения центральной нервной системы, а в Липецкой области выявлен один (100 \%) больной ЛЗН с нейроинвазивной формой.

Преобладающими клиническими формами течения ЛЗН в сезон 2015 г. были среднетяжелые, которые составили в среднем по России 75,6\% (в 2014 г. - $67 \%$ ); в том числе в Краснодарском крае $100 \%$, Астраханской области - 93, Ростовской - 60. Завозной случай ЛЗН из Таиланда (Санкт-Петербург) также имел среднетяжелое течение. 
Доля заболеваний с тяжелым клиническим течением составила в 2015 г. 9,8\% (в 2014г. - 3\%). Летальный исход зарегистрирован в Астраханской области у больного 78 лет, что составило 2,4\% в среднем по России (в 2014 г. летальных случаев ЛЗН не зарегистрировано).

Доля городского населения среди заболевших ЛЗН в сезон 2015 г. составила более половины от зарегистрированного числа случаев - $68 \%$, как и в сезон 2014 г. В Ростовской, Воронежской, Липецкой областях и Краснодарском крае этот показатель составил 100 \%, в Саратовской - 90. Данные показатели свидетельствуют прежде всего о более высоком качестве диагностики ЛЗН в крупных городах, однако в отдельных регионах, например, в Астраханской области, система диагностики ЛЗН эффективно налажена и в населенных пунктах сельской местности, о чем свидетельствует то обстоятельство, что большинство из зарегистрированных случаев ЛЗН выявлено в данном регионе среди сельских жителей (67 \% от общего числа случаев в 2015 г., 67 \% - в 2014 г.).

Анализ эпидемической ситуации по ЛЗН в целом по России позволил выявить тенденцию изменения возрастной структуры больных, наметившуюся в последние годы. Так, доля выявляемых больных до 49 лет постепенно увеличивается: в эпидсезон 2015 г. она составила 53,7 \% , в 2014 г. - 52, 2013 г. 48. Уменьшается доля больных возрастной категории 60 и более лет. Если в 2013 г. она составляла $25 \%$, то в 2014 г. - 22, а в 2015 г. - 19. Наибольшая доля выявленных больных ЛЗН в 2015 г. была в возрастной категории 50-59 лет и составила 26,8 \% (в 2014 г. $26 \%$, в 2013 г. - 17). Однако эпидемические проявления на разных территориях имеют свои особенности, которые необходимо учитывать при планировании конкретных профилактических мероприятий. Например, в Ростовской области среди выявленных больных превалирует возрастная категория 30-39 лет, на долю которой приходится 60 \% всех случаев, а в Самарской области больные этого возраста составили 50 \%. В Астраханской и Самарской областях среди заболевших значительна (20-25\%) доля детей от 1 до 14 лет, в то время как в целом по России заболеваемость детей до 14 лет составила в 2015 г. $9 \%$.

При анализе показателя социальной и профессиональной принадлежности выявленных больных ЛЗН установлено, что 36,5 \% (наибольший показатель в среднем по РФ в 2015 г.) составляли неработающие граждане трудоспособного возраста, а рабочих и служащих (в равных долях - по 14,6 \%) было больше, чем в группе пенсионеров (12\%). Эти показатели также имеют особенности на разных территориях: в Саратовской области больные ЛЗН среди неработающего населения трудоспособного возраста составили 70 \%, в Липецкой - 100 .

Впервые за весь период наблюдения за ЛЗН число заболевших мужчин (в среднем по РФ за 2015 г.) значительно превысило число заболевших женщин (61 и 39\% соответственно); мужчины составляли в Воронежской области - 100 \%, Ростовской -80 , Саратовской -70 .

По результатам эпидемиологического расследования случаев ЛЗН в 2015 г. установлено, что $61 \%$ заболевших заразились по месту проживания: как в городах, так и в сельских поселениях (в 2014 г. по месту проживания заразилось 74 \%, а в 2013 г. - 48) $[2,3]$. Заражение по месту проживания в городе составило $29 \%$ (в 2014 г - $37 \%$ ), а в загородных местах массового отдыха - 14,6 \% (в 2014 г. - $11 \%$ ). За пределами РФ заражение произошло в 2,4 \% случаях (в 2014 г. - 3,7\%).

Климатические характеристики эпидемического сезона по ЛЗН 2015 г. соотносятся с общим трендом климатических изменений последнего десятилетия, для которого характерно постепенное сокращение продолжительности весеннего сезона, раннее наступление лета, которое на значительной территории России было жарким, а также удлинение зимнего периода. Анализ колебаний температурных режимов демонстрирует продолжающуюся тенденцию потепления во все сезоны, кроме зимнего в отдельных географических регионах, в частности, в Восточной Сибири. Наиболее заметное потепление в зимнее время происходит на западе европейской территории РФ и востоке Якутии, зимой и весной - на юге Краснодарского края и в Предбайкалье, весной и осенью - на Чукотке и в Магаданской области.

Обозначенные климатические особенности различных сезонных периодов 2015 г. в РФ, безусловно, оказали влияние на численность популяций основных переносчиков ЛЗН. Наблюдаемое в 2015 г. снижение численности переносчиков на большей части эндемичных по ЛЗН территорий в Южном, Приволжском, Центральном и Северо-Западном федеральных округах, явилось ведущим фактором, определившим развитие эпидемической ситуации по ЛЗН.

Так, в эпидемический сезон 2015 г. в Волгоградской области, наиболее интенсивном очаге ЛЗН, больных не выявлено. Это, вероятно, было следствием климатических и гидрологических условий весны и лета, которые были неблагоприятными для переносчиков и резервуаров ВЗН (кровососущих комаров и перелетных водоплавающих птиц). Паводок на реках области был маловодным, сброс воды в Волго-Ахтубинскую пойму оказался минимальным. В июне-августе при полном отсутствии осадков и высоких температурах воздуха произошло резкое сокращение площадей или пересыхание постоянных водоемов - мест выплода основных переносчиков ВЗН и гнездования диких водоплавающих птиц. Последние были вынуждены мигрировать в регионы с более комфортными гидрологическими условиями и богатой кормовой базой. Сходная ситуация сложилась в Калмыкии, где из-за пересыхания существенно сократилась площадь Сарпинских озер - основного места гнездования перелетных птиц. В то же время в ряде регионов климатические условия оказались более благоприятными. В Саратовской и Самарской 
областях (Приволжский федеральный округ) в апреле, мае и июне осадков выпало до $182 \%$ среднегодовых норм, в Ростовской и Астраханской областях (Южный федеральный округ) - до $211 \%$.

Во всех регионах Южного Федерального округа, которые представили в Референс-центр сведения по энтомологическим наблюдениям, показатели численности комаров рода Culex были ниже среднемноголетних. В Волгоградской области при учете автоматическими ловушками в период максимальной активности переносчиков в городских условиях среднесезонный показатель численности (ССП) 2015 г. составил 59,2 экз., ССП 2014 г. - 157,1; в природных биотопах - 11,3 и 23,2 соответственно. В Ростовской области при учете по методу Гуцевича в природных биотопах ССП - 0,4 экз., среднемноголетний - 1,0.

В большинстве регионов Приволжского Федерального округа ССП численности комаров рода Culex в 2015 г. был незначительно ниже среднемноголетних показателей. В Республике Башкортостан в городских условиях на дневке он составил 1,2 экз. на $1 \mathrm{M}^{2}$, среднемноголетний - 1,4, в природных биотопах на 1 взмах сачка - 7,1 экз., среднемноголетний 8,6. В Самарской области в природных биотопах 2,7 экз., среднемноголетний - 3,8 (без определения рода комаров).

В Уральском Федеральном округе мониторинг численности комаров рода Culex проводился только в Курганской области. В этом регионе ССП в городских условиях и природных биотопах были на уровне среднемноголетних значений.

В Северо-Кавказском Федеральном округе ССП превысил среднемноголетние показатели в городских условиях в Ставропольском крае и Республике Ингушетия, в природных биотопах - в Республике Северная Осетия-Алания.

В Сибирском Федеральном округе ССП численности имаго в Республике Хакасия и Забайкальском крае в городских и природных биотопах были на уровне среднемноголетних показателей, а в Красноярском крае ССП численности личинок в городских биото-

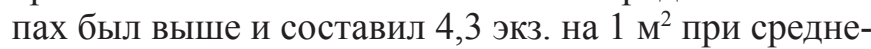
многолетнем - 2,6.

В большинстве регионов Центрального Федерального округа показатели численности комаров рода Culex в городских условиях и природных биотопах были ниже среднемноголетних показателей. В Брянской области при учете по методу Гуцевича ССП имаго комаров этого рода в городских условиях составил 3,6 эк3., среднемноголетний 61,8 ; в природных биотопах - 3,5 и 126 экз. соответственно. В Липецкой области в городских биотопах среднесезонный показатель - 8,8 экз., среднемноголетний $-21,7$.

В Новгородской области (Северо-Западный Федеральный округ) ССП составил 0,7 экз. на м², что ниже среднемноголетнего показателя - 1,6.

Наибольшее количество больных ЛЗН в эпидемический сезон 2015 г. выявлено в группе больных, имеющих симптоматику и первоначальный диагноз «ОРВИ», что соответствует многолетним данным.

Все больные в 2015 г. имели лабораторное подтверждение ЛЗН выявлением ТИФМ IgM в титре выше диагностического. В материале от больного из Саратовской области и умершего из Астраханской области выявлена РНК ВЗН методом ОТ-ПЦР. При исследовании выделенного фрагмента РНК из материала от умершего больного из Астраханской области методом секвенирования участков геномных локусов ProtC, NS3, Prote, NS5 установлен 1а генотип ВЗН.

Активное выявление больных лихорадкой Западного Нила среди лихорадящих больных и больных, имеющих другие симптомы, сходные с ЛЗН, проводилось в 2015 г. в лечебно-профилактических учреждениях 49 субъектов РФ (в 2014 г. - 53, 2013 г. 77). Анализ данных показателей за последние три года демонстрирует сокращение числа субъектов РФ, участвующих в этой работе и, как следствие, снижение количества обследованных больных, включая очаговые территории. Так, в 2015 г. количество обследованных на ЛЗН в Волгоградской области составило 191 человек (в 2014 г. - 215, 2013 г. - 1216), Астраханской - 798 (в 2014 г. - 965, 2013 г. - 1982), в Краснодарском крае - 51 человек (в 2014 г. - 390, 2013 г. - 522). В Ставропольском крае выявление больных ЛЗН по-прежнему остается на низком уровне. В 2015 г. обследовано всего 2 человека (в 2014 г. 2, 2013 г. -9); в других субъектах Северо-Кавказского федерального округа, как и Крымского, эта работа не проводится совсем.

Результаты мониторинга возбудителя ЛЗН, проведенные учреждениями Роспотребнадзора: ФКУЗ ЦГиЭ в субъектах, Региональными центрами по мониторингу за возбудителями инфекционных болезней на базе научно-исследовательских противочумных институтов, противочумными станциями были представлены в Референс-центр из 71 субъекта РФ (в 2014 г. - 65, в 2013 г. - 61) [2, 3]. Мониторинг возбудителя ЛЗН в объектах внешней среды проводился в сезон 2015 г. в 71 субъекте РФ (в 2014 г. - в 61) [3]. Маркеры ВЗН в носителях обнаружены на территории 11 субъектов (в 2014 г. - 9). Антигены ВЗН выявлены в материале: от клещей Dermacentor marginatus в Республике Ингушетия; комаров An. maculipennis в Краснодарском крае; кряквы и комаров Aedes bechningi в Воронежской области; от общественной полевки, сороки, большого баклана, комаров Aedes cinereus в Ростовской области; клещей Dermacentor marginatus, лесных мышей в Самарской области; чайки серебристой, большой синицы и варкуши в Саратовской области. РНК ВЗН обнаружена в материале от клещей Hyalomma marginatus в Республике Калмыкия; утки-касатки в Хабаровском крае; комаров Culex pipiens u Culex modestus, а также от лошадей в Астраханской области; чайки серебристой в Волгоградской области; комаров Culex pipiens в Липецкой области. 
При исследовании Референс-центром вирусной РНК, выделенной из суспензии головного мозга большой синицы из Саратовской области, методом секвенирования участков геномных локусов 5 'UTRprotC, ProtE, NS3 установлен 2-й генотип В3Н.

В эпидемический сезон 2015 г. мониторинг возбудителя ЛЗН при обследовании отдельных здоровых групп населения проводился в 57 субъектах (в 2014 г. - 58). Антитела IgG к ВЗН найдены у населения в 27 субъектах РФ (в 2014 г. - 25) [2].

При обследовании доноров специфические антитела к ВЗН выявлены у $2 \%$ обследованных лиц в Ивановской, 0,5 - в Липецкой, 8 - в Смоленской областях, 1 - в Республике Коми, 3 - в Красноярском крае, 14,5 - в Астраханской, 16,4 - Волгоградской, 4,2 Ростовской, 1,3 - Нижегородской, 6 - Саратовской, 8,3 - Челябинской областях. У животноводов IgG антитела к ВЗН найдены в 3,7 \% от обследованных лиц в Рязанской области, $20 \%$ - в Мурманской области. При сероэпидемиологическом обследовании взрослого населения отдельных территорий $\mathrm{IgG}$ к В3Н выявлены в $1 \%$ от обследованных лиц в Брянской области, 5,9 - Воронежской, 5 - Московской, 2 Орловской, 1,3 - Архангельской, 3,4 - Мурманской областях, 45 - Республике Алтай, 44 - Красноярском крае, 60 - Республике Хакасия, 4 - Забайкальском крае, 5,8 - Пензенской, 5 - Самарской, 2,4 - Саратовской областях, 17,2 - Республике Удмуртия, 2 Ульяновской, 2,9 - Курганской, 4 - Тюменской областях, 0,2 - Санкт-Петербурге. Во Владимировской области при обследовании медицинских работников ЛПУ в $3 \%$ случаев найдены антитела $\mathrm{IgG}$ к В3Н.

Наличие IgG к ВЗН у здорового населения свидетельствует о продолжающейся циркуляции ВЗН на территориях субъектов РФ. На территориях, эндемичных по клещевому энцефалиту, данные о серопозитивности в отношении ЛЗН нуждаются в дополнительной верификации, ввиду выраженных перекрестных иммунологических реакций в группе арбовирусов.

В результате анализа данных мониторинга за возбудителем ЛЗН на территории РФ в период 19992015 гг. установлено, что маркеры ВЗН выявлялись в 61 субъекте Российской Федерации. Выявлена циркуляция нескольких геновариантов ВЗН. В европейской части России циркулирует 1a, 2-й и 4-й геноварианты вируса.

В 2010-2011 гг. Референс-центром методом секвенирования РНК ВЗН, выделенных от больных из Волгоградской, Воронежской и Ростовской областей, определен генотип 2 (lineage 2) В3Н, а от больных из Астраханской области - генотип 1 (1a). В 2012 г. В3Н генотипа 1а выделен из материала от больных из Ставропольского края. Важно отметить, что в этот же период на территории Астраханской области в комарах видов C. richardii $u$ A. hyrcanus в единичных случаях выявлен ВЗН генотипа 2. В 2013 г. из материала от больных Волгоградской и Саратовской областей выделен генотип 2 (lineage 2) В3Н, а
Астраханской области - В3Н генотипа 1а. Генотип 2 (lineage 2) ВЗН определен в пулах комаров рода Aedes из Волгоградской области. В 2014 г. генотип 2 (lineage 2) В3Н выделен в материале от больных людей и комаров рода Cx. pipiens u Cx. modestus из Волгоградской области. В 2015 г. из материала умершего жителя Астраханской области выделен генотип $1 \mathrm{a}$, а от синицы из Саратовской области - генотип 2 (lineage 2) ВЗН. Генотип 4 вируса ЛЗН ранее выявлен в клещах Dermacentor marginatus в Краснодарском крае, комарах Uranotaenia unguiculata и озерных лягушках Rana ridibunda в Волгоградской области [1].

На территории Западной Сибири, по данным Омского научно-исследовательского института природно-очаговых инфекций и Института химической биологии и фундаментальной медицины СО РАН, в Омской, Курганской и Новосибирской областях выделен ВЗН как 1a, так и 2 генотипов [4]. Так, в северных лесостепных биотопах Омской области генотипы 1а и 2 В3Н выявлены в материале нидиколов из гнезд грачей и береговых ласточек, пробах органов грачей (взрослых особей и птенцов). В южной лесостепи Омской области вирус ЛЗН генотипов 1а и 2 обнаружен в нидиколах из гнезда береговой ласточки, клещах Ixodes lividus, Ixodes persulcatus. В Новосибирской области, в Приобье, 2-ой генотип ВЗН выявлен в клещах Ixodes pavlovskyi, в северной лесостепи в нидиколах из гнезд грачей - генотип 1а ВЗН. В Курганской области в пробах органов ондатры Ondatra zibethicus выявлен 1а генотип [4].

Ранее установлена циркуляция В3Н генотипа 1a, сходного с астраханским геновариантом, как среди мигрирующих, так и среди оседлых видов птиц на юге Западной Сибири, в Красноярском и Приморском краях. ВЗН генотипа 1а также выявлен в пробах от диких перелетных и оседлых птиц, мелких млекопитающих и иксодовых клещей в Новосибирской области, в частности, в Томске и пригородах. В3Н 1а генотипа обнаружен в клещах Ixodes pavlovskyi и Ixodes persulcatus [1].

Таким образом, в эпидемический сезон 2015 г. на территории РФ зарегистрирован 41 случай ЛЗН в 9 субъектах РФ. Один летальный случай - в старшей возрастной категории (старше 70 лет). Интенсивность эпидемических проявлений ЛЗН была низкой, характерной для межэпидемического периода. В работу по мониторированию возбудителя ЛЗН и его маркеров включены, в той или иной степени, учреждения Роспотребнадзора 71 субъекта Российской Федерации. Наличие маркеров вируса лихорадки Западного Нила установлено в 2015 г. на 11 территориях РФ, а наличие иммунитета у населения к ВЗН на 27. Всего за период наблюдения 1999-2015 гг. маркеры В3Н обнаружены на территории 61 субъекта РФ. Исследованиями Референс-центра по мониторингу за возбудителем ЛЗН установлено, что в 2015 г. на территории Астраханской области циркулировал 1а генотип В3Н, а на территории Саратовской области - 2-й генотип. 
Следует отметить, что в ряде субъектов РФ результаты мониторирования возбудителя ЛЗН, проводимые учреждениями Роспотребнадзора, недостаточно учитываются медицинскими учреждениями, которые не проводят лабораторные исследования на ЛЗН у больных, что может иметь негативные последствия при активизации эпидемического процесса.

В отношении прогноза развития эпидемиологической ситуации по ЛЗН в 2016 г. необходимо отметить следующее. По оценкам Всемирной метеорологической организации, Всемирного банка реконструкции и развития, других международных организаций, а также Института глобального климата и экологии Росгидромета РФ и РАН, в различных климатических зонах в разные сезоны года изменения гидрометеорологического режима (температурного режима, режима осадков, гидрологического режима рек и водохранилищ, режима морей и устьев рек) будут проявляться по-разному. На большей части территории России ожидается дальнейшее повышение температуры воздуха зимой примерно на $1{ }^{\circ} \mathrm{C}$ с определенными вариациями в различных регионах страны. Летом, в целом, ожидаемое потепление будет слабее, чем зимой. В среднем оно составит $0,4^{\circ} \mathrm{C}$. Температурная аномалия для всей территории страны за последние 20 лет составила $+1,98^{\circ} \mathrm{C}$, а в Восточной Сибири средняя за лето температура была выше на $2,0-3,0^{\circ} \mathrm{C}$, в Сибири продолжается рост средних летних температур на $1,1^{\circ} \mathrm{C}$.

Основной причиной положительных температурных аномалий является глобальное потепление. С начала постоянных наблюдений за климатом (1880 г.) все чаще фиксируются температурные «выбросы», а высокие среднегодовые температуры следуют друг за другом: в 1995, 1997, 1998, 2005, 2010, 2014, 2015 гг. Ряд экспертов предполагает, что и 2016 г. может стать аномально жарким. Свою лепту внесет феномен ЭльНиньо - аномальное повышение температуры в экваториальной части Тихого океана, которое оказывает огромное влияние на формирование мирового климата. По оценкам МЧС России, в 2016 г. на большей части территории России температура будет соответствовать среднемноголетним показателям.

Климатические изменения оказывают комплексное и часто неоднозначное воздействие на ареалы распространения инфекционных болезней и интенсивность эпидемического процесса. В аномально теплые годы, сезоны, отдельные месяцы создаются благоприятные условия для резкого повышения распространенности трансмиссивных инфекций. Региональные изменения климата, особенно повышение температуры и выпадение осадков, будут влиять на разнообразную совокупность физических и биологических систем носителей, определяющих эпидемическую ситуацию по ЛЗН на территории каждого субъекта.

В связи с продолжающейся общей тенденцией изменения климатических условий в Российской Федерации в сторону потепления, следует ожидать дальнейшего выявления циркуляции ВЗН в объектах внешней среды и появления случаев заболевания на более северных территориях.

За период наблюдения за эпидемическим процессом ЛЗН установлено, что маркеры ВЗН выявляются практически на большей части территории РФ. Данный факт подтверждает потенциальную опасность инфицирования населения ЛЗН при благоприятных для развития эпидемического процесса температурных режимах и гидрологических условиях на большей части территории страны.

Интенсивность эпидемических проявлений на территории старых очагов европейской части России, наиболее вероятно, будет невысокой, характерной для межэпидемического периода. Количество выявленных легких и среднетяжелых форм ЛЗН будет зависеть от качества их выявления в лечебнопрофилактических учреждениях. Учитывая тенденцию сокращения объемов обследований на ЛЗН больных, проводимых ЛПУ, будет увеличиваться удельный вес нейроинвазивных форм и случаев тяжелого клинического течения.

Выявление больных ЛЗН среди населения на территориях Северо-Кавказского, Крымского, Центрального, а также южных территориях Дальневосточного и Сибирского федеральных округов возможно при создании условий в ЛПУ для диагностики больных, включая подготовку медицинских кадров и активизацию организационной работы Управлений Роспотребнадзора.

Референс-центр по мониторингу за возбудителем ЛЗН благодарит руководителей и сотрудников Управлений Роспотребнадзора, Центров гигиены и эпидемиологии субъектов Российской Федерации, а также противочумных институтов и противочумных станций Роспотребнадзора, предоставивших данные для проведения эпидемиологического анализа, peзультаты которого изложены в настоящей работе.

Конфликт интересов. Авторы подтверждают отсутствие конфликта финансовых/нефинансовых интересов, связанных с написанием статьи.

\section{СПИСОК ЛИТЕРАТУРЫ}

1. Путинцева Е.В., Антонов В.А., Викторов Д.В., Смелянский В.П., Жуков К.В, Мананков В.В., Погасий Н.И., Ткаченко Г.А., Шпак И.М., Снатенков Е.А. Особенности эпидемической ситуации по лихорадке Западного Нила в 2012 г. на территории Российской Федерации. Пробл. особо опасных инф. 2013; $1: 25-9$.

2. Путинцева Е.В., Антонов В.А., Смелянский В.П., Пакскина Н.Д., Скударева О.Н., Викторов Д.В., Ткаченко Г.А., Пак В.А., Жуков К.В., Монастырский М.В., Бородай Н.В., Мананков В.В., Погасий Н.И., Шпак И.М., Савченко С.С., Лемасова Л.В., Бондарева О.С., Замарина Т.В., Баркова И.А. Особенности эпидемической ситуации по лихорадке Западного Нила в 2013 г. в мире и на территории Российской Федерации и прогноз ее развития в 2014 г. Пробл. особо опасных инф. 2014; 2: 33-9.

3. Путинцева Е.В., Смелянский В.П., Пак В.А., Бородай Н.В., Жуков К.В., Мананков В.В., Погасий Н.И., Ткаченко Г.А., Лемасова Л.В., Леденева М.Л., Пакскина Н.Д., Викторов Д.В., Антонов В.А. Эпидемическая ситуация по лихорадке Западного Нила в 2014 г. в мире и на территории Российской Федерации и прогноз ее развития в 2015 г. Пробл. особо опасных инф. 2015; 1:36-41.

4. Якименко В.В., Ткачев С.Е., Макенов М.Т., Василенко А.Г., Тикунова Н.В. Обнаружение вируса лихорадки Западного Нила 
на юге Западной Сибири. В кн.: Сб. трудов Российской научнопрактической конференции в связи с 50-летием со дня организации Тюменского научно-исследовательского института краевой инфекционной патологии. Тюмень; 2015. Т. 2. С. 224-32.

5. Preliminary Maps \& Data for 2015 [Internet]. Centers for

Disease Control and Prevention (CDC), USA [cited 29 Dec 2015].

Available from: http://www.cdc.gov/westnile/statsMaps/preliminaryMapsData/index.html.

6. Surveillance of West Nile Virus 2015 [Internet]. Public

Health Agency of Canada [cited 21 Dec 2015]. Available from: http:// healthycanadians.gc.ca/diseases-conditions-maladies-affections/disease-maladie/west-nile-nil-occidental/surveillance-eng.php\#s1.

7. West Nile virus - Multistate (Europe) - Monitoring season 2015 [Internet]. Communicable Disease Threats Report (CDTR) Week 47, 15-21 November 2015 [cited 21 Dec 2015]. The European Centre for Disease Prevention and Control (ECDC). Available from: http://ecdc.europa.eu/en/publications/Publications/communicabledisease-threats-report-21-nov-2015.pdfReferences.

\section{References}

1. Putintseva E.V., Antonov V.A., Viktorov D.V., Smelyansky V.P., Zhukov K.V., Manankov V.V., Pogasy N.I., Tkachenko G.A., Shpak I.M., Snatenkov E.A. [Peculiarities of epidemiological situation on West Nile fever in 2012 in the territory of the Russian Federation]. Probl. Osobo Opasn. Infek. in 2012 in the

2. Putintseva E.V., Antonov V.A., Smelyanskiy V.P., Pakskina N.D., Skudareva O.N., Viktorov D.V., Tkachenko G.A., Pak V.A.., Zhukov K.V., Monastirskiy M.V., Boroday N.V.., Manankov V.V., Pogasiy N.I., Shpak I.M., Savchenko S.S., Lemasova L.V., Bondareva O.S., Zamarina T.V., Barkova I.A. [The features of West Nile fever epidemiological situation in the world and Russia in 2013 and prognosis of its development in 2014]. Probl. Osobo Opasn. Infek. 2014; 2:33-9.

3. Putintseva E.V., Smelyansky V.P., Pak V.A., Borodai N.V., Zhukov K.V., Manankov V.V., Pogasiy N.I., Tkachenko G.A., Lemasova L.V. Ledeneva M.L., Pakskina N.D., Viktorov D.V., Antonov V.A. [Epidemic situ- ation on West Nile fever in 2014 in the territory of the Russian Federation and around the world, and prognosis for its development in 2015]. Probl. Osobo Opasn. Infek. 2015; 1:36-41.

4. Yakimenko V.V., Tkachev S.E., Makenov M.T., Vasilenko A.G., Tikunova N.V. [West Nile virus detection in the south of West Siberia]. In: [Collected Works of the Russian Scientific-Practical Conference, Devoted to the $50^{\text {th }}$ Anniversary since the Day of Establishment of Tyumen Research Institute of Territorial Infectious Pathology]. Tyumen; 2015. Vol. 2. P. 224-32.

5. Preliminary Maps \& Data for 2015 [Internet]. Centers for Disease Control and Prevention (CDC), USA [cited 29 Dec 2015]. Available from: http://www.cdc.gov/westnile/statsMaps/preliminaryMapsData/index.html.

6 . Surveillance of West Nile Virus 2015 [Internet]. Public Health Agency of Canada [cited 21 Dec 2015]. Available from: http://healthycanadians.gc.ca/diseases-conditions-maladies-affections/disease-maladie/west-nilenil-occidental/surveillance-eng.php\#s1.

7. West Nile virus - Multistate (Europe) - Monitoring season 2015 [Internet]. Communicable Disease Threats Report (CDTR), Week 47, 15 21 November 2015 [cited 21 Dec 2015]. The European Centre for Disease Prevention and Control (ECDC). Available from: http://ecdc.europa.eu/en Prevention and Control (ECDC). Available from: http://ecdc.europa.eu/en/
publications/Publications/communicable-disease-threats-report-21-nov-2015. pdfReferences.

\section{Authors:}

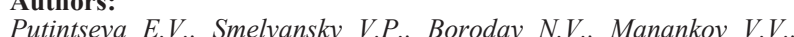
Tkachenko G.A., Shpak I.M., Viktorov D.V., Toporkov A.V. Volgograd Research Anti-Plague Institute. 7, Golubinskaya St., Volgograd, 400131, Russian Federation. E-mail: vari2@sprint-v.com.ru

\section{Об авторах}

Путинцева Е.В., Смелянский В.П., Бородай Н.В., Мананков В.В., Ткаченко Г.А., Шпак И.М., Викторов Д.В., Топорков А.В. Волгоградский научно-исследовательский противочумный институт. Российская Федерация, 400131, Волгоград, ул. Голубинская, 7. E-mail: vari2@ sprint-v.com.ru

Поступила 26.01.16. 